\title{
SCHOOL CLIMATE DESCRIPTION, ASSESMENT \\ AND MEASUREMENT
}

\author{
Jana Kantorová
}

\section{Summary}

This paper analyses the quality of the school climate. One of its objectives is to define such basic terms as environment, atmosphere, climate, and selected climate variants, above all the school climate. Attention is also paid to the following five areas of school life, which are in my opinion of significance: 1) the overall attitude to school and the motivation to study 2) teachers' qualities and competence 3) school rules and the discipline in class 4) the solidarity of the class as a social group 5) the architectural, aesthetic and hygienic aspects of the school. The thesis also wants to present new practical methods supported by long experience of the school climate gained abroad and even by similar experience lately picked up in this country. Whereas in Europe and elsewhere the school climate is part of the basic educational disciplines, in this country it is still waiting for its recognition as a regular educational and psychological phenomenon. The primary aim of the whole thesis is to devise an adequate method, ie a questionnaire for my own research. This questionnaire has been tested in a quantitative way. It has helped me judge the quality of five areas of the school climate at a grammar school. One-factor analysis of dispersion has revealed differences in pupils, teachers and parents' judgement of the five areas. If we compare the average answers given by the three groups of the respondents, we come to the conclusion that it is teachers who are most satisfied with all areas of the school climate. Parents have turned out to be less content. The biggest dissatisfaction is among pupils. In the future the gained results can become a basis for further research in this area. The long-term goal should be to propose a model of creation of a positive school climate in the form of practical advice and recommendations for teachers and headmasters. The importance of the thesis consists in setting up a questionnaire method and carrying out the actual research.

\section{Key words}

School climate, students, teachers, parents, research, questionnaire. 


\title{
Charakteristika, hodnocení a měření školního klimatu
}

\begin{abstract}
Abstrakt
V příspěvku se zabýváme zjištováním kvality školního klimatu. Jedním z obecných cílů textu je teoretické vymezení základních pojmů - prostředí, atmosféra, klima, vybrané varianty klimatu s důrazem na školní klima. Rovněž sledujeme pět vybraných oblastí školního života, které pokládáme za významné - celkový vztah a motivace ke škole, kvality a kompetence učitelů, pravidla ve škole a kázeň ve vyučování, soudržnost tř́dy jako sociální skupiny, architektonické, estetické a hygienické aspekty školy. Příspěvek si také klade za cíl přinést nové praktické metody opřené o dlouhodobé zahraniční, a v dnešní době už i naše zkušenosti se školním klimatem. Zatímco v zahraničí, a to jak v Evropě, tak i jinde ve světě, je oblast školního klimatu součástí základních pedagogických disciplín, u nás tento fenomén teprve hledá své pevné místo a stejnou důležitost jako ostatní pedagogicko-psychologické jevy. Nejdůležitějším záměrem celé práce je vypracovat adekvátní výzkumnou metodu (dotazník) pro vlastní výzkum. V rámci empirického šetření jsme kvantitativním výzkumem ověřovali vytvořené dotazníky pro studenty, učitele a rodiče. Pomocí nich jsme posuzovali kvalitu pěti oblastí školního klimatu na gymnáziu. Jednofaktorovou analýzou rozptylu jsme zjistili rozdíly v hodnocení daných oblastí z hlediska studentů, učitelů a rodičů. Srovnáme-li průměrné odpovědi všech tří skupin respondentů, dojdeme k závěru, že všem oblastem školního klimatu vystavili nejlepši vysvědčení učitelé. Uprostřed stojí hodnocení rodičů. Nejhorší pohled mají na tuto problematiku studenti. Získané výsledky se pro nás mohou stát v budoucnu výchozím materiálem pro další výzkumné aktivity v této oblasti. Jako dlouhodobý záměr vidíme snahu navrhnout model tvorby pozitivního školního klimatu pro učitele a ředitele škol (praktické rady a doporučení). Přínos práce vidíme zejména $\mathrm{v}$ konstrukci dotazníkové metody a realizaci samotného výzkumu.
\end{abstract}

\section{Klíčová slova}

Školní klima, studenti, učitelé, rodiče, výzkum, dotazník.

\section{The term school climate specification}

In our point of view, it is essential to think about the school climate in the wider context. I.e. not just from the perspective of the contemporary events, 
but also due to the past and with the perspective to the future. All aspects of the school life exist in mutual relation. The processes going on in the school life are the reflection of the changes realized in the past and together with that, they have the adaptational and anticipational character. The processes and circumstances in the school environment should be observed with respect to the contemporary conditions. At once, it is necessary to confront the contemporary state with the perspective and benefit for the future. While judging the school climate, we should therefore study the whole evolution of the school environment.

The experts cannot agree on the fact what the term school climate includes and what it does not. Obdržálek (2002) states, that the school climate is a socila-pschological phenomenon which is very complex and exceptionally challenging for the analysis and exploration. Mareš (2000, p. 242) names the school equipment, processes happening in the school, the leadership style, the public reflection of the school, teachers dedication to school and school work; and students specifics as its variables. There have also appeared some provoking opinions that the term school climate is out of use and therefore we should not take care about it. (Finlayson, 1987 in Mareš, 2000, p. 242). We do not share this opinion. We despite concentrate and try to study these problems in the sense of research and theoretical viewpoint.

We know that the school climate (in some sources named as school atmosphere, school world, school life, emotional tone, school ethos, school culture, school spirit) depends on the specific situation of the individual school. It is conditioned by the school environment, where we can observe it, analyse it and evaluate. It does not happen but grows continually. It is the phenomenon which is long-lasting, typical for the individual school.

Some authors describe the term school climate as a school culture, informal perception of the processes which take place at school (Deal a Kennedy, 1985 in Aurin, 1990, p. 58). From our point of view, it is not possible to understand the terms school culture and school climate as the synonyms. There is a mutual relationship between school culture and school climate. This relationship is not one-way but mutual. According to Obdržálek (2002) the school climate influences backwards the school culture after some time, it conditions the satisfaction of the school staff, pupils and teachers. The satisfaction positively influences back the culture of school. In case all individuals feel well and satisfied at school environment, the effectiveness of school increases. Good results of school work serve as a motivation for the other activities and fulfillment of set aims. It is 
possible to confirm the satisfaction of school and their school climate experience participants in the same way.

Spanhel (1993, p. 225) describes the school climate as the perceptional reality or basis, which can be observed at school. Every activity has its meaning in the regular school life. We mainly concentrate on the goal for which the teachers and students would share good relationships in an everyday life of a class or school, would be able to manage the problems or struggles and solve the set tasks together. All theese aspects can be positively influenced by the good school climate. This algorythm works also vice versa. Friendly relations and good mood can help the pleasant school climate. School climate enables the similar perception of the school environment to teachers and students, which they share. We also try to answer the question how we can improve the quality of school and school instruction through good school climate. Every school should try to build its own concept of how it will be optimalizing school climate in an everyday school life.

When judging the school climate we are mostly interested in evaluation of the participating individuals, i.e. students and teachers (compare Eckert, 1988, p. 135; compare Saldern, 1991, p. 190). We also perceive the ideas of headmasters, parents, parent association, school founder or state school authorities. When we study school climate, we can also study the objective data about the school. I.e. the number of students, number and size of classes, school organization, student population, school leadership characteristics, teacher education (Bessoth, 1989). These data do not however speak about the relation among students and teachers, about the student and teacher motivation to instructional activities or cooperation among the students. For us, the more important features are the subjective views of the school acteurs, their ways of thinking, attitude orientation, opinions, ways of behaviour or acting etc.

\section{School climate research}

\subsection{The construction of the research method}

For the purpose of school climate research we constructed the questionnaires for three groups of respondents - students, teachers and parents. In the process of research method construction we used some published tools of Freitag (1998). The author realized his research by the end of 20th century at 
18 German schools, where he analysed the influence of some school climate aspects on the health of students and teachers.

At the preresearch phase we optimalized the research method. After the adaptation we constituted the questionnaires for students, teachers and parents, each of which consists of 50 items. The items are devided into five chosen areas which characterize the school climate. The areas follow:

1. overall relationship and motivation towards the school (items no. 1-9),

2. teacher's quality and competences (items no. 10-21),

3. school rules and the classroom discipline (items no. 22-29),

4. coherence of the class as a social group (items no. 30-37),

5. architectural, aesthetic and hygienic aspects of the school (items no. 38-50).

The respondents reflected on the individual statements by the measure how they agree with the individual item. They circled their response on the scale from 1 to 5 ( 1 - totally disagree, 2 - more or less disagree, 3 - cannot say, 4 more or less agree, 5 - absolutely agree).

\subsection{Realization and the way of research results proceeding}

The research took place at one grammar school in Olomouc region. The sample involved 231 students, 27 teachers and 221 parents.

We examined the evaluation of the school climate areas within the individual groups of respondents. We used one-way factor analysis (ANOVA) with the followed comparisson of the mean values through HSD (Tuckey) for unequal sums of comparrison within the groups. The gained results were also interpreted through the qualitative approach. In the paper we focus only on quantitave analysis of the gained data.

\subsection{Research results and discussion}

The research definitely confirmed the differences in evaluation of the areas of school climate from the students, teachers and parents perspective.

In the area "overall relationship and motivation to school", there appeared some differences among the groups of students and teachers, and groups of parents and teachers too. 
In the second area "teacher's quality and competences" were no differences found.

The area "the school rules and the classroom discipline" was approached differently by compared groups of students and teachers, students and parents and parents and teachers.

The fourth area "the coherence of the class as a social group" did not show the differences from students, teachers nor parents perspective.

In the fifth area "architectural, aesthetic and hygienic aspects of school"we found the differences in evaluation of the groups of students and teachers, students and parents, but there were no differences clarified within the groups of teachers and parents.

On the basis of the research results we can assume not just the results in the evaluation of the selected areas. We also deduce which group of respondents evaluates the studied area best and which worst.

The first area "overall relationship and motivation to school" was most positively judged by teachers (average evaluation of 4.23), than parents (3.81) and worst by students (3.65).

In the second are "teacher's quality and competences" the similar results appeared. It was best evaluated by the teachers (3.78), followed by parents (3.56) and worst by students (3.42).

The third area "the school rules and the classroom discipline" was again best viewed by teachers (3.87), parents (3.45) and worst by students (3.32).

The fourth area "coherence of the class as a social group" was positively judged by teachers, (3.40), with similar value by parenst (3.29) and students (3.22).

In the fifth area "architectural, aesthetic and hygienic aspects of school" there were no dramatic changes in evaluation. The area was again best viewed by teachers (3.98). The evaluation of parents (3.62) and students (3.60) was almost the same.

Now we compare average assessments of three groups of respondents - students, teachers and parents. All areas became the best evaluation from teachers, the worst from students, in the middle are parents. 
We can also judge overall assessment of the areas of school climate. The most positively was viewed by all respondents the first area "overall relationship and motivation to school". The worst of all areas was evaluated the fourth area „coherence of the class as a social group“.

In our point of view, some circumstances may occur, which can garble the results of the research. We think that some side factors could play a role in the process of questionaire filling (e.g. personal matters of the respondents) which reflected in the final evaluation of the selected areas of school climate.

However, we do not want to make final conclusion on the basis of these results. We realize that we have to be cautious in the interpretation of the facts. Despite this, we think that evaluation of the selected items of the school climate at a grammar school is more or less optimistic. But we also realize that even the negative aspects of school climate belong to the studied phenomenon. They mean the challenge for improvement and optimalization of the school climate.

\section{Resources}

1. AURIN, K. Gute Schulen - worauf beruht ihre Wirksamkeit?. Bad Heilbrunn/ Obb.: Verlag Julius Kleinkhardt, 1990. ISBN 3-7815-0639-8.

2. BESSOTH, R. Verbesserung des Unterrichtsklimas. Neuwied u Frankfurt a. M.: Luchterhand, 1989. ISBN 3-472-54051-6.

3. ECKERT, T. Veränderungen in der Wahrnehmung schulischer Umwelt. Zeitschrift für Pädagogische Psychologie, 1988, Vol. 2, n 2, pp. 135-143.

4. FREITAG, M. Was ist eine gesunde Schule? Weinheim und München: Juventa Verlag, 1998. ISBN 3-7799-1183-3.

5. KAŠPÁRKOVÁ, J. Výzkumný nástroj pro evaluaci školního klimatu (konstrukce a aplikace v praxi. Olomouc: VUP, 2007. ISBN 978-80-244-1852-0.

6. MAREŠ, J. Sociální klima školy. Pedagogická revue, 2000, Vol 52, n 3, pp. 241-254. ISSN 1335-1982.

7. OBDRŽÁLEK, Z. Škola a jej manažment. Bratislava: UK, 2002. ISBN 80223-1690-3.

8. SALDERN, M. v. Die Lernumwelt aus der Sicht von Lehrern und Schülern. Psychologie in Erziehung und Unterricht, 1991, n 38, pp. 190-198.

9. SPANHEL, D. Die Bedeutung des Schul- und Klassenklimas für Erziehung und Unterricht. Pädagogische Welt, 1993, Vol 47, n 5, pp. 224-237. 


\section{Author:}

PhDr. Jana Kantorová, Ph.D., Department of Education, Pedagogical fakulty of Palacký University, Žižkovo 5, 77140 Olomouc,

Czech Republic,

e-mail: kantor.jana@seznam.cz 